\title{
Integration Physics On Hahslm Theory With Big Bang And Shalat IED
}

\author{
RM Aziz \\ UIN Jakarta \\ hahslm.study@gmail.com
}

\begin{abstract}
Abstrack: The reflexivity research aims to find the consistency of the Theory Hahslm that derived from Quran 15.87 to other empirical study about the creation of universe such as the Big Bang concept and Golden Ratio. Also fasting and creation in Islamic life are analogued with process of creation in universe. After fasting there are two Ied pray that shows about the duration of creation process and the numbers of movement in those two worship. The data was compiled from intrepretation of some sentences in Quran, empirical data about Moslem activities, numerology in modern Mathematic and data of Physics. Metodology used similarity formation method and descriptive analysis. Conslusions are: Allah has an equation to create universe known as Hahslm or 472319. These formula appeared in Quran 21.30 with simplicity of 725, Ied pray as 725 numbers, Golden ratio with equation of $360=72 \times 5$, and Big Bang process. Recommendation is Islamic scholars should use theory Hahslm to integrate the conventional studies. Theoretical implication is the mainstream theory about universe and life should refer to Theory $H$.
\end{abstract}

Keywords: Hahslm, Universe, Big Bang, Golden Ratio, Ied Pray, 725, 472319

\section{INTRODUCTION}

Universe creation has some approached to describe about the process of creating and the formulation. The formaulation is needed to make same perception among scientists to understand the pattern of universe. Some theories explained about the universe creation with different angles. The standard process should be existed to have single formulation about the creation. Some scientists wished if single formulation about the process of creation had been discovered, it means the single theory to explain about everything of science can be conluded.

There are some theories about all sciences in one theory such as Universe Guidance Theory (GUT) by Aziz, Theory Of Everything (TOE) by Hawking, and Connected Universe by Haramein. These theories reflected about how universe created in the first time, because the first formula of the universe are these theories then following life in universe should include of these theories. The differentiation of the approaches could be make different concept, the persistent concept can be found in science if the formula is consistent. If the process of creating universe has element of the equation, but in other science this equation can be implemented, then it means this equation is the answer of one theory for all sciences.

In Quran 21.30 explained about creating universe that universe created from 1 circle to seperate by two thing. Creating process can be studied in an egg, from 1 circle of egg then there are 2 elements seperate know as yellow egg and white egg. The holy book factually as simplicity of the process of creation. But in the reality, scientists should make many analyzes to have empirical statements. The reflexivity of holy book and empirical science can be worked to have study of integration between spirituality and modern science. Guidance Universe Theory (GUT) is the one and only success theory to make combination between Quran and Materialism approach. 
There are some statements from Quran to be fundamental theory for UGT to find Hahslm equation. These statements was analyzed with empirical theory and material samples to make resultant of these different axis angles dimensions. The journey of reflexivity of integration between religion and secular is the long research about integration. Finally, modern science and Islamic science is the one science. Because creating universe has a one way to be live until now. When the universe created in the first time, there is only one formulation to create universe. In this research, the first creation formula is represented by numbers 725 where this numbers can be extracted to be 472319 and this station numbers can be converted into words know as Hahslm. If the first time of creation in universe has a Hahslm equation, then in every single parts of living today in universe should be Hahslm in the system.

Quran 15.87 described about origin of numbers 472319 that converted to Hahslm equation, known as Theory $\mathrm{H}$. This $\mathrm{H}$ Theory can be interpreted as the dominant three archetypal theory with the context specified in the five dimensions of variant susceptibility. Its meaning is the whole set, system, integrated section will consist of 3 main elements those are primary as creator or intermediary, secondary as creation or recipient, tertier as worship or transmitter and there are 2 other elements as constant and error. These 2 elements integrated as supporting conjuction to connect main elements.

This study tends to determine whether there are Islamic values that reflected with Theory $\mathrm{H}$ in the process of formation of the universe or the Big Bang Theory. Formulation of the research problems are: (1) There is one theory to explain all about creation, (2) The linkage among approaches with Theory Hahslm. Answering these research problems, this study will analyze the creation of universe in modern theory such as Big Bang Theory and Golden Ration with other approached such as fasting and Ied pray, also will analyze Allah equation, fasting and Ied pray with the creation of universe that relates with consistency numbers 472319 as Hahslm. Benefit of study about Islam and conventional creation are: Islamic scholars has genuine method compares to conventional theory, regulators can support the integration study to improve Islamic higher education for global standard.

\section{ANALYSIS}

\subsection{Theoretical of Creation In Fasting}

According to modern science, there are at least 4 conditions that can be achieved through fasting. First, as happened to the octopus. The octopus mother who is waiting the birth of a squid baby from 50,000 eggs, was fasting during this process. Fasting for this creature is waiting in a process time of creating something. Until the creation would emerge as a large baby, after octopus did fasting. Fasting 30 days, in the month of Ramadan moslem people are in a process of creation for large new cells, after being fasting actions.

The meaning of month 9th (nineth), the month of Ramadan is a big month as number to give a hint there will be a large creation, after being fasting by humans. The constants of the universe are the number of 72, for example 72 Borobudur Stupas. The number of 72 is a constant for the Creation of the Universe. Fasting is meaningful of there will be a creation, there is a big bang or great creation that will happen after fasting. After fasting for moslem people means a winning, then winning fasting means creating something a new and big or a lot of thing.

Second, the same thing happened to the mother hen who was incubating eggs. The fasting lesson in this context is to preserve the existence of groups or species through the process of regeneration or creation of new body. Third, fasting is also carried out by snakes. The wisdom of fasting in this context is to get flexibility, or adaptability in the journey of life, and 
creating new skin. Fourth, fasting in the style of a cocoon caterpillarlt is easy to help science reflect on the fasting that are doing by creatures living.

\subsection{Ied Prayer Bigbang Bigboth And Golden Ratio}

There is celebration of winning of fasting, it called Ied pray. First Ied pray started from the Ied Adha, then the second Ied pray is Ied Fitri. The distance between first Ied to second Ied is within 9 months and 18 days. This 9,5 month distance almost exatcly the same with process of crreation in human pregnancy. Then definition of creation for this context is to make new birth. Distance 2 Ied prayer, from the Adha Ied Prayer, to the Ied Al-Fitr Prayer, is 9 (nine) months, 17 days, which is close to the length of pregnancy.

Before Ied prayer, moslem people were fasting. It can be compared with the octopus, before 50 thousand squid hatched, the Octopus Mother also fasting. After fasting, moslem carry out the Ied Al-Fitr worship with the provisions of 725 movement, known as 7 takbir, 2 rak'ahs, 5 takbir. Ied worship based on algorythm of 725 can be defined as Big Both. It refers to QS. Al-Anbiya [21]:30 that one dot as circle would be seperated both by 72 and 5. This scircle dot is 360 degree then seperate as $72 \times 5$. Ied worship can be symbolized as Islamic Big Both that would be proved by Quran, Islam, and science with universe that those are consistency in every single creation that had been made by God.

The same with Golden Ratio that has ratio from pentagon form. The first line is length between 2 angles, and second line is the length between the farthest corners. Comparison between these two lines are 1:1,618. This ratio can be found in some structures such as measurements of finger bone of human, and other pattern the ration of 1:1,618 can be found in the spiral of sunflower, form of universe, form of human baby. Pentagon in a circle has 5 corners with the same degrees such as $360=72 \times 5$. The equation of $72 \times 5$ is the same with equation numbers of Ied pray 725. Scholars has concluded that Quran 21.30 explained 1 circle to seperate by two are multipliers equation that is $72 \times 5$ where 72 is the degree of every corner of pentagon, and 5 is the corners in 1 pentagon. So when Quran explained universe was seperated from 1 unit to 2 parts, it means 1 unit is circle 360 degree, and 2 units are 72 and 5 or $72 \times 5$ which is $72 \times 5$ is the golden ratio from pentagon lines.

\subsection{Big Bang and Matter}

Since Dirac's theory as Hole 1928 was confirmed experimentally in 1932 by Anderson, there was a growing consensus among physicists that every material had an antimatter partner. Electrons have antielectron pairs such as positrons. Proton has an antiproton pair. Neutron has an antinetron. Antiquark Quark, and others. The anti-particle has the same quantity, mass, except the electric charge with the particle of the pair. Interestingly if the particles meet their anti-particles as electrons meet positrons, they will disappear and change into photon radiation.

Hypothesis of the big bang theory was first proposed by George Lematitre. This theory states that the origin of the universe starts from a primeval atom or a very solid atom. At the time because it is too dense and has a high energy calor, this atom explodes until all the material is thrown to all corners of the vacuum that surrounds it. Since the explosion, all of the atomic explosion particles (planets, asteroids, meteoroids, etc.) have expanded for thousands of millions of years. From these expansions arises two opposing forces which are the forces of gravity and cosmic repulsion forces. This theory says that sometime, the expansion will definitely stop. This means that in general, this theory contradicts the theory of the fixed state of knowing the creation and the end. 
In the Big Bang concept, antimatter and matter occur symmetrically. It started with a big boom about 12-20 billion years ago. This was the beginning of the creation of matter, energy, and time. "Explosion" is essentially the development of space. The first material formed is the hydrogen that forms the basis for the first generation stars. The nuclear fusion between hydrogen nuclei, producing heavier elements such as carbon, oxygen, to iron or also called Big Bang Nucleosynthesis. But at one hundredth of a second after the Big Bang or Big Both in the Theory $\mathrm{H}$, there is a deviation in a fundamental process which causes more asymmetry between anti-matter and matter. Every one billion and one or 1,000,000,001 particles, there are one billion or $1,000,000,000$ anti particles. Every 1,000,000,001 protons, there are $1,000,000,000$ antiprotons. Nucleosynthesis of Big Bang occurs in the first three minutes of the creation of the universe and is responsible for many abundance comparisons of $1 \mathrm{H}$ (protium), $2 \mathrm{H}$ (deuterium), 3He (helium-3), and 4He (helium-4), in the universe.Although $4 \mathrm{He}$ continues Are generated by other mechanisms (such as star fusion and alpha decay) and the number of traces $1 \mathrm{H}$ continues to be generated by spalasi and special types of radioactive decay (proton release and neutron release), mostly the mass of these isotopes in the universe, and all Except the insignificant traces of $3 \mathrm{He}$ and deuterium in the universe produced by a rare process such as cluster decay, are thought to be generated in the Big Bang process.

\subsection{Theory H As Hahslm 472319}

Knowing the philosophy of H Theory is necessary deepening ontology which is always associated with Islam both literally and maknawi. Furthermore, the development of opistemology in Islamic institutions that Kaffah presents new terminology becomes a more comprehensive approach. In generally, the philosophy of $\mathrm{H}$ theory can logic sequentially that the background of this theory is the value of Islam with a comprehensive concept through a balanced way to embody the meaning of worship in life.

There is a verse of the Qur'an Surah Al-Hijr [15]: 87 which reads:

Meaning: "And I give you 7 repeated and great Quran" (Q.S Al-Hijr: 87)

According to Roikhan (2015) of the verse, can get the two main variables, 7 (Seven) and the Qur'an, 7 (Seven) are considered absolute variables, and the Qur'an can still be broken down into $2,3,1,9$. If it summed, $2 \times 3 \times 19$ the result is 114 . So that got five numbers, that is $7,2,3,1,9$. To facilitate in making the formula, the numbers are converted into letters. In these numbers it can be seen 7 being A (Alif), 2 being h (hanif), 3 being S (sin / Human), 1 being L (Lam / Lillah) and 9 being M (Mim / Masjid). So AhSLM is formed. To make it an equation, a dependent variable is required. The variable is $\mathrm{H}$ (Huda / Hint). Huda is derived from the number 4 . The number 4 , comes from the sum of $7+2+3+1+9=22$. (22) becomes $2+2=4$. Finally the equation is formed $H=A . h(S, L, M)$.

Diagram SLM and Universe

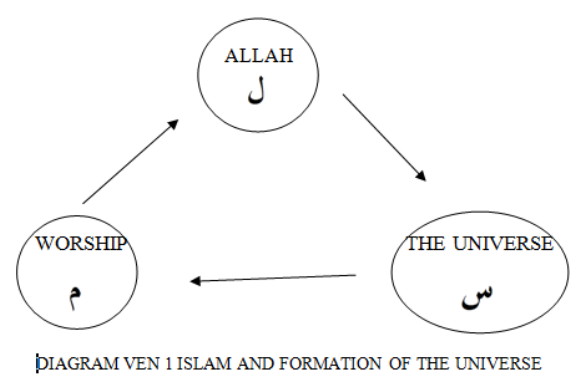

Source: Analyzed, 2019 
There are comparison between theory and empirical data. The theory can explain the concept of $\mathrm{H}$ theory that the Universe ( $\sin$ ) and the whole is created by Allah (lam) only to worship (mim). God is symbolized as Lam because Allah is the most creative substance

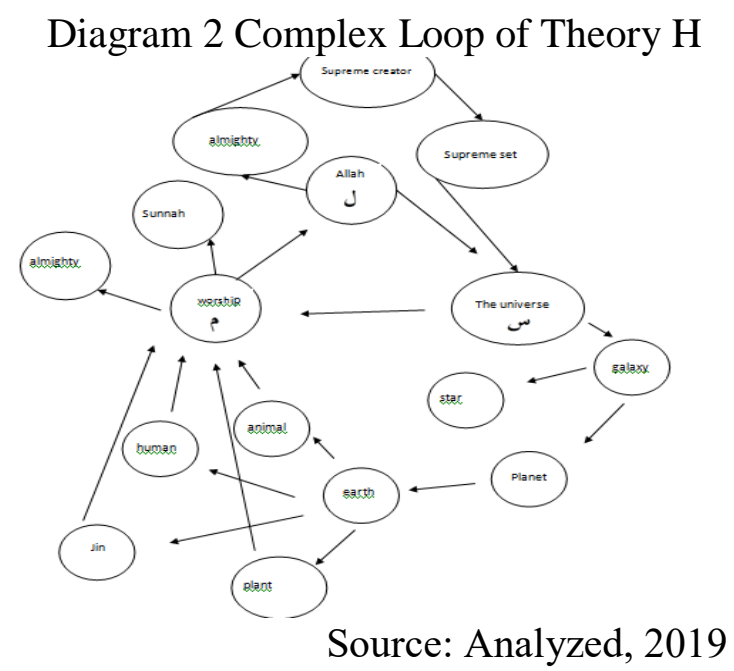

In the diagram above, there are specification to explain from the diagram 1 a simple diagram. In this diagram 2, God created the universe and control all its contents, a universe containing from several galaxies, in which galaxies are made up of several stars and planets. In this case planet Earth because only Planet earth that has life and there are humans, plants, animals, and jin who will worship to Allah until the Day of Judgment.

\section{CONCLUSION}

Creation of universe has numerology of 725 where 5 can be intrepreted as 3,1, and 9. Nine is the 1 character with the biggest number, that is 9 . Then there are numbers: 72 and 319 with dependent number 4. So the number of creating universe of 725 is equal to 472319 as the Hahslm formula.

There are some conclusions reflexivity to creating universe:

1. The one and only equation to explain creating universe that integrated within Islam and modern science is Hahslm 472319 known as Theory $\mathrm{H}$.

2. Theory $\mathrm{H}$ can be used in every single creation in universe because those elements has originated from different dimensions.

Recommendation is Islamic scholars should use theory Hahslm to integrate the conventional studies. And theoretical implication is the mainstream theory about universe and life should refer to Theory $\mathrm{H}$.

\section{REFERENCES}

Aziz, Roikhan Mochamad. 2005. Sinlammim Kode Tuhan. Esa Alam, Jakarta.

Aziz, Roikhan Mochamad. 2006. Jejak Islam Yang Hilang. Sinlammim, Jakarta.

Aziz, Roikhan Mochamad. October 2008. The Application Of Mathematics In Information System Based On Al-Quran. Working Paper, Studium General, State Islamic University (UIN) Jakarta, Indonesia.

Aziz, Roikhan Mochamad. October 2008. The Mistery of Digital Root Based On Sinlammim Method. Proceeding. Institut Teknologi Bandung (ITB). Bandung, Indonesia. 
Aziz, Roikhan Mochamad. October 2008. The Root Of Mathematics And Science Is level Compared With Religious Thinking. Proceeding. State Islamic University (UIN) Jakarta, Indonesia.

Aziz, Roikhan Mochamad. 2009. Kaffah Thinking on Sinlammim Method Through Digital Root. Proceeding, ISOIT International Seminar on Islamic Thought, UKM, Bangi, Malaysia.

Aziz, Roikhan Mochamad. 2009. Education on Root Of Islam. Proceeding, International Seminar On Islamic Education. UNJ, Jakarta.

Aziz, Roikhan Mochamad. October 2009. Kaffah Thinking on Sinlammim Method Through Digital Root. Proceeding, UKM Malaysia.

Aziz, Roikhan Mochamad. 2010. Islamic Civilization Versus western System. Proceeding. International Conference on Islamic Civilization. Kahorem Pakistam.

Aziz, Roikhan Mochamad. 2010. Education on Root of Islam. Proceeding International Seminar Islam's Contribution in Education to Empower Human Resources.

Aziz, Roikhan Mochamad. 2011. New Paradigm on System Thinking. Jurnal Ekonotika. Fakultas Ekonomi Bisnis, Jurusan Ilmu Ekonomi Studi Pembangunan (IESP), Jakarta.

Aziz, Roikhan Mochamad. 2014. Islamic Physics. Proceeding of Islam, Science, and Civilization UIN Walisongo dan Universitas Teknologi Malaysia.

Aziz, Roikhan Mochamad. 2015. Rumus Tuhan Hahslm Dalam Ekonomi. Buku Program Seminar Nasional Fakultas Ekonomi Universitas Terbuka.

Aziz, Roikhan Mochamad. Agustus 2015. Rumus Tuhan Hahslm Dalam Berpikir Menyeluruh Sebagai Metodologi Ekonomi Islam. Procedding ICIEF15: Strengthning Islamic Economics and Financial Institution for Financial Institution for the Welfare of Ummah. Universitas Mataram, Lombok.

Aziz, Roikhan Mochamad. September 2015. Hahslm Islamic Economics Methodology. Procedding ICOSEC: Developing Countries Readiness Toward Global Universitas Negeri Solo, Surakarta.

Aziz, Roikhan Mochamad. 2016. Teori H Sebagai Wahyu Dan Turats Dalam Islam. Jurnal Ushuluddin Vol 24 No 1. Universitas Islam Negeri Riau.

Aziz, Roikhan Mochamad. 2017. Islam Dan Pengetahuan. Salemba Diniyah, Jakarta.

Aziz, Roikhan Mochamad. 2019. Religion And Epistemology Reflexivity of Islam. Proceeding, Iconist, UIN Malang.

Aziz, Roikhan Mochamad. 2019. Hahslm Equation In Quran Al-Hijr 15.87. Proceeding, Iconquhas, UIN Bandung.

Djamil, A.S. 2004. “Al Qur'an dan Lautan”. Bandung: P.T.Mizan Pustaka.

Cecep, Subarya. 2010. "Pemodelan dan Estimasi Dinamika Pergerakan Lempeng Tektonik di Wilayah Indonesia dari Pengamatan GPS".

Djamaluddin 2008. "Proses Penciptaan Alam Semesta dalam Enam Masa". https://misykatulanwar.wordpress.com/2008/06/10/proses-penciptaan-alam-semestadalam-enam-masa/ Diakses pada tanggal 12 Oktober 2016.

Jamarudin, Ade 2010. "Konsep Alam Semesta Menurut Al-Qur'an" http://ejournal.uinsuska.ac.id/index.php/ushuludin/article/view/670/ Diakses pada tanggal 12 Oktober 2016

Ministry of Religion RI. 2012. "Penciptaan Bumi dalam Perspektif Al-Qur'an dan Sains". Jakarta: Sinergi Pustaka Indonesia. 